\title{
ETIKA PENULISAN DAN ATRIBUT WEBSITE INSTITUSI PENDIDIKAN
}

\author{
Ir. Tri Mulyono, MT
}

\begin{abstract}
Abstrak
Internet berkembang tanpa batas ruang dan waktu termasuk batas administrasi. Administrator Web hendaklah memerhatikan etika penulisan dan atribut website apalagi sebagai lembaga pendidikan. Etika penulisan content website yang menjadi perhatian utamanya menghindari kejahatan penelitian/hak cipta yaitu fabrikasi, falsifikasi dan plagiarisme. Paling sering kejahatan hak cipta adalah plagiatisme. Atribut website adalah kelengkapan utama sebagai sebuah halaman website, sebagai institusi pendidikan atribut website antara lain lokasi, informasi umum, profil mahasiswa, fasilitas fisik, elibrary, kerjasama, dan lainnya. Tulisan ini mencoba menjelaskan etika penulisan dan atribut website dalam sebuah institusi pendidikan yang merupakan rujukan sebagai kajian pustaka dalam membuat sebuah tulisan publikasi ilmiah di dunia maya.
\end{abstract}

Kata Kunci: Etika, Atribut, Institusi Pendidikan

\section{Pendahuluan}

Perkembangan sistem informasi telah banyak menggunakan komputer sebagai alat bantunya. Pemanfaatan teknologi komputer pada Sistem Informasi juga terus mengalami perkembangan yang luar biasa. Dari model mainframe, minicomputer, PC standalone sampai pada teknologi LAN, yang dapat menghubungkan setiap komputer pada suatu lokasi lokal saja. Salah satu teknologi yang sudah mulai dirasakan manfaatnya saat ini adalah. Internet, suatu jaringan global yang dapat menghubungan semua host (computer) di dunia ini. Seperti pada konsep jaringan lokal LAN, dengan terhubungnya setiap host pada jaringan global, memungkinkan untuk saling bertukar informasi, dokumen dan resource antar user maupun komputer. Jangan heran jika ternyata saat ini sedang trend untuk memanfaatkan teknologi Internet, terutama WWW, dalam membangun sebuah Sistem Informasi baru (Susanto, 1998).

Etika Penulisan Dan Atribut Website Institusi Pendidikan (Tri Mulyono, Dosen Jurusan Teknik Sipil FT- UNJ) 
Dalam waktu yang relatif singkat semenjak Internet pertama kali terbuka penggunaannya untuk pemakaian umum pada tahun 1986, jaringan komunikasi ini telah merambah dengan kecepatan luar biasa ke seluruh pelosok dunia tak terkecuali Indonesia. Menurut data terakhir, pada tahun 1999 lebih dari 100 juta orang menggunakan Internet dan jumlah tersebut masih terus akan bertambah, seiring dengan bertambahnya kesadaran orang akan perlunya informasi dan semakin banyaknya kemudahan-kemudahan yang bisa didapat melalui Internet.

IDC memperkirakan ada 196 juta pengguna Internet di seluruh dunia sampai akhir tahun 1999, dan diramalkan akan menjadi 502 juta pengguna pada tahun 2003. Kegiatan berinternet akan bertambah dua kali lipat setiap 100 hari, dan diperkirakan pada tahun 2005 sebanyak 1 milliar penduduk dunia akan tergabung dan terhubung satu sama lian melalui jaringan Internet. Data per-2001 (Yuhetty, 2002) menunjukan Internet Service Providers sebanyak 40 provider dengan rata-rata kecepatan akses 15 KBPS. Dari ISPs tersebut digunakan oleh sekitar 198 juta pengguna (dengan kurang dari 1\% pengguna Indonesian).

Pengguna internet terdiri dari $42 \%$ untuk komersial, $30 \%$ pendidikan tinggi, 21\% pemerintah, $6 \%$ lembaga penelitian, and 1\% kantor-kantor swasta. Berdasarkan pekerjaan pengguna dibagi untuk pelajar 39\%, karyawan $22 \%$, manajer $17 \%$, asisten manajer $5 \%$, professionals $5 \%$, direktur $4 \%$, entrepreneurs $3 \%$, dan lainnya $5 \%$. Sedangkan berdasarkan latar belakang pendidikan untuk pengguna berlatar belakang pendidikan dasar dan menengah (SD/SMP) 2\%, SMA 41\%, Diploma 9\%, Sarjana 43\%, and Pascasarjana 5\%. Berdasarkan hasil penelitian pengguna internet paling banyak menggunakan internet saat mereka berada di kantor $70 \%$ sisanya saat mereka berada di rumah ataupun melalui warnet.

Perkembangan pengguna internet di Indonesia menurut Asosiasi Penyelenggara Jasa Internet Indonesia (APJII) pada tahun 1998 sekitar 512.000 orang, tahun 2001 sebanyak 4,2 juta dan sampai dengan akhir tahun 2004 mencapai 11.226.143 orang diperkirakan akhir 2005 sebanyak 16 juta pengguna. Rata-rata penambahan pengguna sekitar 2.2 juta/tahun (APJII, 2005). Pengguna sebanyak 4,2 juta orang tahun 2001 tersebut terdiri dari 550 ribu pengguna perumahan, 26 ribu pengguna perusahaan, 2000 sekolah

MENARA, JURNAL TEKNIK SIPIL VOL. I, NO. 2 JULI 2006: 120-135 
dengan rata-rata 500 pengguna/siswa persekolah, 500 perguruan tinggi dengan rata-rata 1000 mahasiswa per kampus dan 2500 warnet dengan ratarata 100 orang pelanggan perwanet (Hardjito, 2002)

Kesempatan untuk mengakses Internet juga semakin terbuka lebar bagi pengguna yang tidak memiliki komputer sendiri, dengan bermunculannya warung internet (warnet) yang tersebar dipelosok kota-kota besar. Warnet yang pada tahun 1999 di ibukota (Jakarta) masih bisa dihitung dengan jari, kini merebak di berbagai pelosok. Sementara itu kesadaran masyarakat baik dari kalangan content provider maupun khalayak pengguna juga cukup menggembirakan. Apalagi didukung dengan kecepatan akses yang semakin tinggi yang mana saat ini bahkan ada yang telah mencapai 2 Gbps (jika didukung finance yang cukup).

\section{Mengapa Mempublikasi Tulisan Di Internet}

Perkembangan ilmu pengetahuan terjadi melalui kreativitas dan skeptisisme, keterbukaan pada kontribusi ilmu baru, serta kegigihan dalam mempertanyakan kontribusi yang diberikan dan konsensus keilmuan yang berlaku. Perkembangan teknologi tentunya juga mempengaruhi perkembangan ilmu pengetahuan secara berarti (Toha, 2005).

Suatu tulisan (essay) merupakan suatu usaha untuk mengkomunikasikan informasi, opini atau perasaan (feeling), dan biasanya juga menampilkan argumen tentang topik tertentu (UVic, 1995). Beberapa alasan praktis mengapa kita menulis adalah ingin mendapatkan penghargaan sebagai seorang scientist (sebagai dosen adalah nilai kredit) baik itu dikalangan masyarakat akademis ataupun masyarakat lainnya. Secara ideal dalam membuat suatu tulisan hendaknya kita berharap dapat memberikan kontribusi pada Ipteks.

Alasan secara teknis tulisan yang kita buat adalah sebagai dasar penelitian lanjutan, mengatasi kelemahan Komunikasi lisan, melaporkan hasil kerja ilmiah dan sarana promosi diri atau suatu lembaga/institusi.

Mengapa di Internet? Hal ini dapat dijawab karena internet merupaka sarana yang dapat menyebarkan informasi tanpa batas ruang dan waktu. Sehingga khalayak sasaran strategis dari suatu tulisan dapat lebih luas tercapai, dan lebih banyak lagi dapat dicapai adalah khalayak sasaran antara 
apalagi didukung dengan penggunaan bahasa internasional. Alasan lain mengapa menggunakan internet karena upaya kita untuk menjadikan konsep tentang manajemen Paperless dapat tercapai.

\section{Etika Penulisan Website}

Pengertian yang lebih sempit tentang permasalahan etika ilmiah/penelitian adalah apa yang dikategorikan sebagai kejahatan penelitian (research misconduct). Tiga hal yang secara nyata dikategorikan kejahatan penelitian: Pertama fabrikasi (fabrication) yaitu mengarang (making up) data, eksperimen, atau informasi yang signifikan dalam mengusulkan, melakukan, atau melaporkan penelitian. Kedua falsifikasi adalah mengubah atau mengaburkan data atau eksperimen, atau mengaburkan sesuatu yang signifikan. Dan Ketiga Plagiarisme adalah menyalin sesuatu, atau menampilkan grafik atau gagasan orang lain, yang dinyatakan atau terkesan sebagai hasil dirinya. Plagiarisme ini termasuk kategori pelanggaran kepemilikian intelektual (ABET, 2001, Whitbeck, 1998).

Dari ketiga hal yang secara nyata dikategorikan sebagai kejahatan penelitaian tersebut, hal yang kritis yang dapat secara tidak sadar terjebak pada kategori ini adalah plagiarisme. Oleh karena itu penulis artikel ilmiah harus secara sadar dan jelas menyatakan menggunakan sumber atau hasil penelitian orang lain, serta harus mengikuti tata-cara dan aturan penulisan cuplikan atau acuan (citation) suatu tulisan/artikel ilmiah yang berlaku. Pernyataan atau acuan dalam suatu tulisan/artikel ilmiah merupakan bentuk penghargaan pada peneliti lain.

Etika dalam penulisan materi di internet akan menuntut dan mewajibkan kita untuk mencantumkan sumber atau tanggal mendownload file dimana alamat sumbernya dapat berbentuk website/url: http, gopher, ftp, jika pencipta mensyaratkan ijin maka kita dapat menghubungi alamat biasanya tercantum di bagian bawah halaman website atau melalui administrasi web/webmaster melalui email hal ini dimaksudkan untuk menghindari plagiatisme. Dalam bibliografi dianjurkan agar referensi yang bersumber dari internet dinyatakan seperti contoh di daftar pustaka.

Kode etik sebagai seorang Penulis baik itu merupakan artikel di website atau lainnya maka memperhatikan dan menjaga kebenaran hakiki yaitu 
menuliskan informasi dan sumber ataupun hasil karya secara jelas. Penggunaan bahasa yang mudah di mengerti dalam hal untuk penggunaan kalangan akademis sebaiknya menggunakan bahasa ilmiah popoler. Penggunaan bahasa ilmiah yang populer dimaksudkan agar artikel atau isi yang dibuat enak dibaca yang akhirnya meningkatkan jumlah pengguna website. Dalam penulisan artikel di internet sebaiknya menggunakan bahasa yang ringkas/singkat dan lugas, karena artikel atau isi yang panjang dalam suatu halaman website akan membutuhkan waktu yang lama dalam membukanya, sehingga untuk pengguna yang pembosan cenderung akan meninggalkan halaman yang dibuka.

\section{Materi/Content Penulisan}

Materi atau Isi dalam suatu halaman web di internet dapat berupa hanya sekedar informasi dan promosi sampai ke hal-hal yang sifatnya sangat ilmiah, seumpamanya hasil suatu karya penelitian. Materi dalam halaman internet yang merupakan dan bersumber dari suatu lembaga pemerintah (go/gov), lembaga perguruan tinggi (ac/edu) ataupun majalah ilmiah, organisasi, komersial (org/com), pada umumnya dapat dipercaya. Namun demikian hasil akhir tingkat kepercayaan ini tetap ditangan pembaca.

Secara umum sebagian besar di antara bahan artikel yang ditayangkan (posted) di internet merupakan hasil karya ilmu pengetahuan, teknologi dan seni (ipteks). Maksud tujuan utama penayangan di internet tersebut agar karya artikel tersebut dapat dengan mudah diakses untuk dipahami, dipelajari, dikembangkan oleh webster atau oleh siapa saja (public community) yang berminat untuk dijadikan sebagai acuan atau referensi bagi pembaca kucuali dinyatakan lain. Penggunaan material atau artikel atau lainnya yang bersumber dalam tayangan internet perlu memperhatikan etika yaitu menghormati pengarang/hak cipta (Tarumingken, 2005).

Materi atau isi (content) yang berkualitas selalu akan dicari pengguna, dan juga search engine. Pengertian materi website disini adalah teks, gambar, dan flash yang dapat dinikmati pengguna secara langsung. Sebuah website bisa dikatakan memiliki materi berkualitas, apabila bisa menyajikan informasi yang bermanfaat bagi pengguna, unik (tidak sekedar meniru), dan yang

Etika Penulisan Dan Atribut Website Institusi Pendidikan (Tri Mulyono, Dosen Jurusan Teknik Sipil FT- UNJ) 
terakhir bisa diakses secara luas oleh seluruh atau sebagian besar pengguna internet (Aryadana, 2001) .

Materi website yang kita tulis sebaiknya benar-benar merupakan hasil karya kita sendiri dan bukan hasil menjiplak/menyalin dari website lain. Jika Anda mengutip sebagian Materi dari suatu sumber, apapun medianya, hendaknya copyright dari si penulis harus dicantumkan dan menyebutkan darimana content tersebut diambil. Pengertian mengutip adalah mengambil sebagian kecil, bukan seluruhnya. Lebih baik lagi kalau Anda meminta izin terlebih dahulu kepada si penulis website, karena langkah ini menunjukkan bahwa Anda menghargai hak cipta dari seseorang.

\section{Tahap Penulisan Content}

Dalam menulis suatu artikel atau isi dari halaman website dimulai dari bagian yang paling mudah sampai kemudian judul atau heading tulisan merupakan mungkin yang paling akhir. Selanjutnya proses pengendapan yaitu proses pemahaman dan pembacaan lebih detail mengenai isi materi dan dilakukan secara berulang-ulang sambil dilakukan penyuntingan sendiri. Koreksi oleh pihak lain akan sangat membantu terhadap kemudah mengertian pembaca terhadap isi materi dan atau kesalahan dalam penulisan (Achmadi, 2005). Pada tahapan selanjutnya adalah melakukan upload atau publikasi di internet. Dalam penulisan judul atau heading sebuah halaman website sebaiknya singkat dan spesifik. Hindari penggunaan kata-kata yang tak lazim atau tak populer.

Halaman pertama dalam suatu website hendaklah berupa informasi umum, jangan pernah membuat suatu halaman pertama dari website untuk hanya sekedar tahu bagi seorang pengguna internet untuk membukanya saja membutuhkan waktu yang lama. Isi halaman pertama dalam sebuah web berisi informasi yang singkat dan lugas. Halaman selanjutnya barulah berisi tentang detail-detail dari informasi yang hendak ditayangkan. Terlepas dari hal-hal tersebut, ada satu faktor lagi yang harus mendapat perhatian, yaitu etika penulisan untuk menghargai hak cipta.

\section{Definisi Hak Cipta}

Indonesia melalui Undang-Undang RI Nomor 19 Tahun 2002 Tanggal 29 
Juli 2002 tentang Hak Cipta mendefinisikan pengertian hak cipta, pencipta, ciptaan dan pemegang hak cipta adalah sebagai berikut:

1. Hak Cipta adalah hak eksklusif bagi Pencipta atau penerima hak untuk mengumumkan atau memperbanyak Ciptaannya atau memberikan izin untuk itu dengan tidak mengurangi pembatasan-pembatasan menurut peraturan perundang-undangan yang berlaku.

2. Pencipta adalah seorang atau beberapa orang secara bersama-sama yang atas inspirasinya melahirkan suatu Ciptaan berdasarkan kemampuan pikiran, imajinasi, kecekatan, keterampilan, atau keahlian yang dituangkan kedalam bentuk yang khas dan bersifat pribadi.

3. Ciptaan adalah hasil setiap karya Pencipta yang menunjukkan keasliannya dalam lapangan ilmu pengetahuan, seni, atau sastra.

4. Pemegang Hak Cipta adalah Pencipta sebagai Pemilik Hak Cipta, atau pihak yang menerima hak tersebut dari Pencipta, atau pihak lain yang menerima lebih lanjut hak dari pihak yang menerima hak tersebut.

\section{Kejahatan Plagiatisme}

Penjiplakan materi hasil karya seseorang secara illegal juga sangat membahayakan posisi Anda di search engine. Misalnya, jika Anda menyalin materi sebuah website secara illegal, dan si pemilik materi mengetahui hal ini, ia dapat melaporkan hal tersebut sebagai pelanggaran hak cipta kepada admin dari berbagai search engine utama. Google misalnya, memiliki chanel khusus untuk menerima laporan mengenai pelanggaran hak cipta. Pihak Google akan memeriksa hal ini, sebab mereka juga tidak ingin meng-index halaman-halaman yang mempunyai materi illegal. Mereka cukup pintar untuk membedakan kebenaran dari sebuah laporan. Misalnya, halaman website jiplakan selalu muncul setelah halaman website aslinya. Dan yang kedua, teknologi pagerank juga bisa membantu mendeteksi dengan melihat referensi dari website-website lain yang memasang link ke website asli. Jika sudah terdeteksi, apa akibatnya ? Tentu saja website jiplakan tersebut akan di-black list. Pada posisi ini jangan harap untuk dapat terlisting kembali dalam search engine. Jadi apapun alasannya penjiplakan materi secara illegal sebaiknya kita hindari. Disamping untuk menghargai hasil karya orang lain, hal ini juga akan membuat kita lebih kreatif dalam berkreasi.

Etika Penulisan Dan Atribut Website Institusi Pendidikan (Tri Mulyono, Dosen Jurusan Teknik Sipil FT- UNJ) 


\section{Keamanan Jaringan}

Eksistensi teknologi informasi disamping menjanjikan sejumlah harapan, pada saat yang sama juga melahirkan kecemasan-kecemasan baru antara lain munculnya kejahatan baru yang lebih canggih dalam bentuk Cyber Crime. Disamping itu, mengingat teknologi informasi yang tidak mengenal batas-batas teritorial dan sepenuhnya beroperasi secara maya (virtual), teknologi informasi juga melahirkan aktivitas-aktivitas baru yang harus diatur oleh hukum yang berlaku saat ini. Kenyataan ini telah menyadarkan masyarakat akan perlunya regulasi yang mengatur mengenai aktivitas-aktivitas yang melibatkan teknologi informasi. Hal ini untuk menjaga pelanggaran hak cipta.

Internet meupakan salah satu produk gabungan teknologi komputer dan telekomunikasi (ICT) yang sukses. Internet yang pada awalnya ditujukan untuk kepentingan militer saat ini telah digunakan sebagai media untuk melakukan bisnis dan kegiatan sehari-hari. Yang sering menjadi pertanyaan adalah tingkat keamanan dari teknologi internet. Keamanan di internet sebetulnya sudah pada tahap yang dapat diterima, hanya hal ini perlu mendapat pengesahan dari pemerintah atau otoritas lainnya sehingga pelaku bisnis mendapatkan kepastian hukum.

Identitas seseorang dapat diberikan dengan menggunakan digital signature (tanda tangan digital) yang dikelola oleh Certification Authority (CA). Permasalahannya adalah tanda tangan digital ini harus dapat dianggap sebagai alat bukti yang sah setelah melalui prosedur dan mekanisme keamanan yang tinggi. Kejahatan yang ditimbulkan oleh teknologi komputer dan telekomunikasi perlu diantisipasi. Istilah hacker, cracker, dan cybercrime telah sering terdengar dan menjadi bagian dari khazanah hukum pidana, Kejahatan yang melibatkan orang Indonesia sudah terjadi. Ada juga kejahatan yang dilakukan oleh pengguna di Indonesia dengan tidak menggirimkan barang atau uang yang sudah disepakati dalam transaksi e-commerce. Tindak kejahatan semacam ini pada umumnya dapat ditelusuri (trace) dengan bantuan catatan (logfile) yang ada di server ISP yang digunakan Cracker. Akan tetapi seringkali ISP tidak melakukan pencatatan (logging) atau hanya menyimpan log dalam kurun waktu yang singkat. Logfile ini dapat menjadi bukti adanya akses cracker tersebut. Penyidikan kejahatan cyber ini membutuhkan keahlian khusus. Pihak ahli hukum harus lebih cepat tanggap 
dalam menguasai teknologi baru ini. (Soemadiningrat, 2005)

\section{Dasar Hukum}

Indonesia melalui RUU tentang Teknologi Informasi, dalam pasal 2 RUU tentang pemanfaatan teknologi informasi disebutkan bahwa kegiatan teknologi informasi harus diselenggarakan berdasarkan asas kemanfaatan dan kemitraan dengan mengutamakan kepentingan nasional, persatuan dan kesatuan, menghormati ketertiban umum, kesusilaan, serta menjunjung tinggi etika (Soemadiningrat, 2002).

Selanjutnya pada Pasal 3 disebutkan bahwa pengaturan pemamfaatan teknologi informasi harus dilaksanakan dengan tujuan untuk:

1. Mendukung persatuan dan kesatuan bangsa serta mencerdaskan kehidupan bangsa sebagai bagian dari masyarakat informasi dunia;

2. Mendukung perkembangan perdagangan dan perekonomian nasional dalam rangka meningkatkan kesejahteraan masyarakat dan pertumbuhan ekonomi nasional;

3. Mendukung efektivitas komunikasi dengan memanfaatkan secara optimal teknologi informasi untuk tercapainya keadilan dan kepastian hukum; (4) Memberikan kesempatan seluas-luasnya kepada setiap orang untuk menggembangkan.

UU HAKI No. 19 Tahun 2002 Pasal 12 ayat (1) dalam Undang-undang ini Ciptaan yang dilindungi adalah Ciptaan dalam bidang ilmu pengetahuan, seni dan sastra, yang mencakup :

a. buku, Program Komputer, pamflet, perwajahan (lay out) karya tulis yang diterbitkan, dan semua hasil karya tulis lain;

b. ceramah, kuliah, pidato, dan Ciptaan lain yang sejenis dengan itu;

c. alat peraga yang dibuat untuk kepentingan pendidikan dan ilmu pengetahuan;

d. lagu atau musik dengan atau tanpa teks;

e. drama atau drama musikal, tari, koreografi, pewayangan, dan pantomim;

f. seni rupa dalam segala bentuk seperti seni lukis, gambar, seni ukir, seni kaligrafi, seni pahat, seni patung, kolase, dan seni terapan;

Etika Penulisan Dan Atribut Website Institusi Pendidikan (Tri Mulyono, Dosen Jurusan Teknik Sipil FT- UNJ) 
g. arsitektur;

h. peta;

i. seni batik;

j. fotografi;

k. sinematografi;

1. terjemahan, tafsir, saduran, bunga rampai, database, dan karya lain dari hasil pengalihwujudan.

Jelas dalam pasal 12 (1) butir a. Lay-out atau perwajahan dalam suatu halaman web juga merupakan karya cipta, dan butir j fotografi seringkali muncul dan digunakan dalam suatu halaman website. Penggunaan tanpa ijin merupakan pelanggaran. Masa berlaku ciptaan selama hidup Pencipta dan terus berlangsung hingga 50 (lima puluh) tahun setelah pencipta meninggal dunia (Pasal 29).

Sanksi hukum terhadap pelanggaran hak cipta menurut pasal 72 UU HAKI No.19 Tahun 2002 adalah dipidana dengan pidana penjara masingmasing paling singkat 1 (satu) bulan dan/atau denda paling sedikit Rp. 1.000.000,00 (satu juta rupiah), atau pidana penjara paling lama 7 (tujuh) tahun dan/atau denda paling banyak Rp. 5.000.000.000,00 (lima miliar rupiah). Dan Barangsiapa dengan sengaja menyiarkan, memamerkan, mengedarkan, menjual kepada umum suatu Ciptaan atau barang hasil pelanggaran Hak Cipta atau Hak Terkait dipidana dengan pidana penjara paling lama 5 (lima) tahun dan/atau denda paling banyak Rp. 500.000.000,00 (lina ratus juta rupiah).

\section{Atribut Website}

Pengertian atribut menurut sendiri dalam kosa kata Bahasa Indonesia tidak secara jelas, karena pengertian atribut berasal dari Bahasa Inggris yaitu Attribute. Atribut merupakan kelengkapan dari suatu struktruk utama, dapat diartikan secara bebas atribut merupakan asesoris yang utama yang mencirikan sesuatu sehingga dapat menarik minat yang melihatnya.

Atribut sebuah lembaga institusi pendidikan tidak terlepas dari ciri Tridharma perguruan tinggi yaitu Pendidikan, Penelitian dan Pengabdian. Akan tetatpi ini ciri ini untuk masing-masing lembaga akan berbeda, baik dalam hal tampilan fisik maupun isi dari masing-masing lembaga tersebut.

Selain itu sebagai Institusi pendidikan "elektronik" hendaknya atribut 
dibangun untuk memenuhi kebutuhan-kebutuhan pembelajaran abad 21 dengan peranan sebagai berikut (Rusmono dan Suharmantri, 2004)

1. memberi informasi tentang kebutuhan-kebutuhan pendidikan dan pelatihan dan peluang-peluang,

2. memberi pengawasan kualitas,

3. memberi akreditasi melalui penilaian belajar yang independen,

4. mengembangkan kurikulum yang koheren dan tepat,

5. menjadi broker dan mensyahkan kursus-kursus dan bahan-bahan pendidikan dan pelatihan dari pemasok,

6. memberi pelayanan penggunaan dan komunikasi bahan-bahan pembelajaran multimedia yang user-friendly baik impor maupun eskpor,

7. membuat jaringan antar pelajar dan antar instruktur,

8. menciptakan bahan-bahan multi-media pendidikan berkualitas tinggi dalam bentuk yang diperoleh,

9. mengadakan penelitian untuk kebutuhan pendidikan dan pelatihan, dan

10. menggunakan teknologi-teknologi baru untuk pengembangan pendidikan dan pelatihan serta mengevaluasi penggunaannya.

Pengguna internet cenderung membuka halaman web lembaga pendidikan yang memberikan informasi yang lengkap sebelum mengunjungi secara langsung. Pengguna internet biasanya akan mencari infomasi mengenai sistem pendidikan untuk kebutuhan studi lanjut dan karya-karya ilmiah sebagai referensi untuk bahan tulisan ataupun penelitian mereka. Atribut halaman website yang baik adalah bagaimana menarik pengguna untuk bertahan lebih lama didepan sebuah komputer yang terkoneksi dalam jaringan internet. Kuncinya adalah tata letak dari sebuah halaman web hal ini akan membuat pengguna internet lebih lama bertahan. Tata letak ini sebaiknya mencirikan panji/warna kebesaran ataupun logo-logo.

Secara umum atribut dari sebuah lembaga institusi yang disajikan dalam sebuah halaman website meliputi Lambang, Panji-panji, himne (lagu) dan informasi tentang tridharma perguruan tinggi. Akan tetapi jika mengartikan atribut lebih luas lagi atribut untuk lembaga pendidikan juga dapat berarti kelengkapan dari terselenggaranya sebuah institusi pendidikan. Jika berpikir secara sistem atribut lembaga pendidikan adalah input (masukan) - proses output (keluaran).

Etika Penulisan Dan Atribut Website Institusi Pendidikan (Tri Mulyono, Dosen Jurusan Teknik Sipil FT- UNJ) 
Atribut lembaga pendidikan dalam web merupakan informasi singkat dan lugas sebagai awal. Atribut ini merupakan masukan (input) adalah infromasi tentang kemudahan akses (Accesibility), sejarah singkat termasuk visi, misi dan renstra serta profil mahasiswa (jika mungkin). Atribut yang dapat dikatagorikan sebagai proses meliputi informasi tentang; proses belajar mengajar (kurikulum, sistem belajar, suasana akademik), SDM (Staf Akademik dan Staf Pendukung), Fasilitas Fisik (Sarana dan Prasarana Pendukung). Sedangkan yang dapat dikatagorikan sebagai atribut dari keluaran meliputi Lulusan (Alumni), produk hasil penelitian dan pengabdian serta prodak lainnya.

\section{Lokasi (Aksesibil;itas)}

Informasi singkat mengenai lokasi atau keberadaan dari lembaga institusi merupakan suatu informasi yang berharga bagi pembaca di internet. Informasi ini merupakan petunjuk singkat mengenai keberadaan lembaga dan bagaimana cara mencapai lembaga tersebut. Jika lokasi lembaga tersebut berada di suatu komplek (misal Fakultas) dan infromasi mengenai Universitas tersebut sudah ditanyangkan di halaman utama, maka informasi lokasi Fakultas diberikan di halaman Fakultas.

\section{Informasi Umum Prodi/Jurusan/Fakultas}

Visi, Misi, Tujuan dan Rencana Strategis dan panji-panji dari masingmasing Prodi/Jurusan/Fakultas akan dapat memberikan informasi singkat bagi penjelah internet. Informasi ini dapat disajikan dalam bentuk narasi singkat.

\section{Profil Mahasiswa}

Informasi yang disajikan dalam atribut ini merupakan tarikan atau untuk membangkitkan ketertarikan (attractiveness) pengguna yang mencari informasi yang berkaitan dengan mahasiswa. Informasi yang disajikan dapat berupa profil singkat suasana belajar mahasiswa, laju pertumbuhan mahasiswa, demografi dan lainnya yang berkaitan dengan kemahasiswaan. Informasi tentang Unit-unit kegiatan mahasiswa juga dapat ditampilkan misalnya kegiatan BEM Jurusan, Fakultas ataupun UKM lainnya. Informasi ini 
dapat disajikan dengan menggunakan ilustrasi (Photo atau clip movie singkat) atau menggunakan narasi.

\section{Fasilitas Fisik (Sarana Dan Prasarana)}

Atribut mengenai fasilitas fisik ini terutama menampilkan sarana ruang belajar (gedung kuliah), laboratorium atau workshop, pusat kajian fakultas (jika ada), ruang dosen, perpustakaan serta fasilitas umum lainnya. Informasi mengenai kelengkapan peralatan baik itu di ruang kelas maupun di laboratorium dan workshop hendaknya juga menjadi perhatian sebagai atribut dari sarana fisik.

Selain kondisi exisiting (jika mungkin ada) termasuk pengembangan dari fasilitas fisik.

\section{Proses Pendidikan}

Informasi tentang proses pendidikan dapat berupa infomasi tentang kemampuan SDM. Kemampuan SDM ini dapat dibuat singkat ataupun lebih detail yang memuat CV dari masing-masing SDM Fakultas/Jurusan/Prodi termasuk informasi keahlian dari masing-masing personil. Informasi tentang kurikulum yang digunakan juga dapat masukkan.

Selain itu pengabdian masyarakat juga dapat dimasukan dalam atribut ini terutama yang berkaitan dengan karya pengabdian mahasiswa.

\section{Perpustakaan Elektronik (E- Library)}

Perpustakaan elektronik merupakan atribut yang paling banyak ada dalam sebuah halaman website pendidikan. Karena umumnya pengguna internet mencari informasi di situs-pendidikan selain untuk mencari informasi tentang sistem pendidikan, lainnya adalah mencari tentang hasil karya penelitian yang pernah dilakukan.

Publikasi secara elektronik dapat dilakukan dengan menampilakan hasil karya penelitian tersebut dalam E-library. Sebagai informasi awal mungkin hanya ditampilkan abstrak dari hasil penelitian tersebut. Untuk mendapatkan data lebih lanjut dan lengkap pengguna internet dapat mendaftar (Jika sistem pengaksesan yang baik, artinya hanya member atau yang telah diberi ijin yang dapat mengakses) atau berkunjung langsung. Pengolahan E-library saat ini sudah bersifat komersial, jika kita mengikuti langkah ini maka bukan tidak 
mungkin kita akan dapat mendapatkan suatu income generated yang significant.

\section{Kerjasama}

Atribut kerjasama dalam sebah halaman website dapat memberikan informasi tentang kinerja keterlibatan stakeholder, institusi lain atau pemerintah baik dalam maupun luar negeri dalam mendukung lembaga penndidikan. Kerjasama ini dapat berupa kerjasama dalam penyelengaraan pendidikan (due program), riset ataupun lainnya.

\section{Penutup}

Berdasarkan uraian di atas hal pertama yang menjadi perhatian bagi pengguna internet adalah bagaimana menghargai Hak Cipta (Copy Right). Pengguna yang ingin mengadopsi sebagian isi di halaman sebuah web haruslah mengetahui etika. Jika ingin mengadopsiseluruh isi maka pengguna haruslah meminta ijin. Pelanggaran ini berarti melanggar undang-undang yang berkaitan dengan hak cipta.

Penggunaan bahasa ilmiah populer dalam sebuah halaman web institusi pendidikan hendaklah menjadi perhatian penting, bahasa yang lugas, singkat dan dapat dengan mudah dimengerti akan menambah ketertarikan pengguna.

Untuk membuat sebuah web institusi pendidikan maka atribut yang berkaitan dengan pendidikan sebaiknya ditampilkan baik dalam bentuk narasi singkat ataupun visual dalam bentuk photo atau clip vidio dengan durasi yang singkat.

Atribut untuk web sebuah intitusi pendidikan tinggi secara singkat meliputi informasi tentang: Lokasi, visi, misi, tujuan dan renstra, profil mahasiswa, proses pendidikan, hasil karya ilmiah (e-library) dan kerjasama yang telah dilakukan ataupun yang akan dilakukan. 


\section{Daftar Pustaka:}

ABET, 2001, Glossary,http://www.abet.org/glossary, Accessed 06 Sept 2005

Achmadi, Suminar Setiati, Penulisan Artikel Jurnal Ilmiah Institut Pertanian

Bogor, http://www.dikti.org/p3m

APJII, Statistik APJII Updated Januari 2005,

http://www.apjii.or.id/dokumentasi/statistik/Asosiasi Penyelenggara Jasa Internet Indonesia1.htm, dikunjungi 9 September 2005.

Aryadana, Ketut, Etika Dalam Penulisan Content Website Copyright (C) 2001 2005 All Rights Reserved". http://www.promosi-web.com. Accessed 07 Sept 2005.

Hardjito, Internet Untuk Pembelajaran. e-Jurnal, http://www.pustekkom.go.id, dikunjungi 20 Pebruari 2005.

Rusmono dan Suharmantri, Bambang, Pembelajaran Berbasis Web Dan Komputer (Computer Dan Web-Based Instruction) 2002. e-Jurnal, http://www.pustekkom.org/teknodik, dikunjungi 20 Pebruari 2005.

Soemadiningrat, R. Otje S, Tinjauan Rancangan Undang-Undang (Ruu) Tentang Pemanfaatan Teknologi Informasi Fakultas Hukum UNIKOM, http://www.solit.8m.com/download/undang_undang_it.htm. dikunjungi tgl: 4 Agustus 2005.

Susanto, Budi, Teknologi Web Untuk Sistem Informasi Pengembangan Aplikasi Web Untuk Mendukung Sistem Informasi Pada Internet Dan Intranet 1, e-Jurnal @ 1998, e-Jurnal, http://www.pustekkom.org/teknodik, dikunjungi 20 Pebruari 2005.

Tarumingkeng, Rudy C, Petunjuk Penggunaan Sumber Internet Untuk Bahan Pustaka Penulisan Karya IImu Pengetahuan Institut Pertanian Bogor: http://tumoutou.net/intern_pub.htm

Toha, Isa Setiasyah, Teknik Dan Etika Penulisan Artikel IImiah Laboratorium Sistem Produksi, Jurusan Teknik Industri ITB: http://lpfilkom.freeservers.com/lain/etika.zip. Download, 07 Sept 2005. 
Undang-Undang Republik Indonesia Nomor 19 Tahun 2002 Tanggal 29 Juli 2002 Tentang Hak Cipta ; http://www.bappenas.org/hukum, dikunjungi tanggal 2 Pebruari 2004.

UNJ, Statuta Unj Jakarta: Universitas Negeri Jakarta, 2004.

UVic, 1995, The Uvic Writer's Guide, http://www.clearcf.uvic.ca/writersguide/Pages/ResearchEssayType.html, Accessed 06 Sept 2005.

Yehetty, Harina, Ict And Education In Indonesia Makalah ini telah disajikan dalam Seminar/Workshop on the Promotion of ICT Education to Narrow the Digital Divide, 15 - 22 October 2002, Tokyo, Japan, e-Jurnal, http://www.pustekkom.org/teknodik, dikunjungi 20 Pebruari 2005. 